Georgetown University Law Center

Scholarship @ GEORGETOWN LAW

2001

\title{
The Sex Discrimination Argument in Gay Rights Cases
}

Nan D. Hunter

Georgetown University Law Center, ndh5@law.georgetown.edu

This paper can be downloaded free of charge from:

https://scholarship.law.georgetown.edu/facpub/1722

9 J.L. \& Pol'y 397-416

This open-access article is brought to you by the Georgetown Law Library. Posted with permission of the author. Follow this and additional works at: https://scholarship.law.georgetown.edu/facpub

Part of the Civil Rights and Discrimination Commons, and the Sexuality and the Law Commons 


\title{
THE SEX DISCRIMINATION ARGUMENT IN GAY RIGHTS CASES
}

\author{
Nan D. Hunter
}

\section{INTRODUCTION}

The argument that laws that discriminate on the basis of sexual orientation in fact discriminate on the basis of sex is not new. Advocates have been pressing this claim for almost thirty years. Simply put, the argument is that a statute that bars a sexual relationship between two women or two men discriminates on the basis of sex because either partner could have had the same relationship with a person of the opposite sex.

The beginning was not auspicious for the sex discrimination argument. Courts considering challenges in the 1970s to marriage laws concluded, with very little need for discussion, that marriage was definitionally an institution involving only male-female couples, and that therefore even a state Equal Rights Amendment could not undo the prohibition on same-sex marriage. ${ }^{1}$ Similarly, courts hearing employment discrimination cases easily concluded that sex discrimination meant discrimination against women or occasionally against men, but not anti-gay discrimination. ${ }^{2}$

That easy dismissal of the sex discrimination argument has begun to erode. The first judicial adoption of this argument came in 1993 in Baehr v. Lewin, in which the Hawaii Supreme Court

* Professor of Law, Brooklyn Law School. Thanks to Chris Fowler for his assistance with research and editing.

${ }^{1}$ See, e.g., Jones v. Hallahan, 501 S.W.2d 588 (Ky. 1973); Baker v. Nelson, 191 N.W.2d 185 (Minn. 1971); Singer v. Hara, 522 P.2d 1187 (Wash. Ct. App. 1974). Accord Dean v. Dist. of Columbia, 653 A.2d 307 (D.C. 1995).

${ }^{2}$ See, e.g., DeSantis v. Pac. Tel. \& Tel. Co., 608 F.2d 327 (9th Cir. 1979); Smith v. Liberty Mutual Ins. Co., 569 F.2d 325 (5th Cir. 1978). 
held that limiting marriage to opposite-sex couples did constitute a prima facie case of violating that state's Equal Rights Amendment. ${ }^{3}$ In 1999, it was taken up and expanded by Justice Johnson as part of the basis for her concurrence in Baker v. Vermont, holding that the Vermont marriage statute violated that state's constitution. ${ }^{4}$ Most recently, the Texas Court of Appeals invalidated a same-sex sodomy statute on that ground as well. ${ }^{5}$

The sex discrimination argument has also begun to gain traction in sexual orientation cases arising under statutes. The Supreme Court has ruled that same-sex harassment claims are justiciable under Title VII, ${ }^{6}$ in response to same-sex sexual harassment complainants who have sought to frame the allegedly unlawful conduct as sex discrimination, either rather than or in addition to sexual orientation discrimination. ${ }^{7}$ Similarly, under Title IX, samesex harassment has been recognized as a subset of sex discrimination. ${ }^{8}$ For example, the Wisconsin state anti-discrimination statute

${ }^{3} 852$ P.2d 44, $81-82$ (Haw.), recons. granted in part, 875 P.2d 225 (Haw. 1993).

474 A.2d 864, 898 (Vt. 1999) (Johnson, J., concurring).

${ }^{5}$ Lawrence v. Texas, No. 14-99-00109-CR, 2000 WL 729417 (Tex. App., June 8, 2000).

${ }^{6}$ Oncale v. Sundowner Offshore Serv., Inc., 523 U.S. 75 (1998); see also Wrightson v. Pizza Hut of Am., Inc., 99 F.3d 138, 143-44 (4th Cir. 1996) (allowing a Title VII claim to proceed where the male plaintiff alleged discrimination by his allegedly homosexual supervisor not because of the plaintiff's heterosexual orientation, but because he was male).

${ }^{7}$ See, e.g., Simonton v. Runyon, 232 F.3d 33 (2d Cir. 2000); Higgins v. New Balance Athletic Shoe, Inc., 194 F.3d 252 (1st Cir. 1999); Doe v. Belleville, 119 F.3d 563 (7th Cir. 1997); McWilliams v. Fairfax County Bd. of Supervisors, 72 F.3d 1191 (4th Cir. 1996); Williamson v. A.G. Edwards and Sons, Inc., 876 F.2d 69 (8th Cir. 1989).

${ }^{8}$ See Montgomery v. Indep. Sch. Dist., 109 F. Supp. 2d 1081 (D. Minn. 2000); Ray v. Antioch Unified Sch. Dist., 107 F. Supp. 2d 1165 (N.D. Cal. 2000); see also Sexual Harassment Guidance: Harassment of Students by School Employees, Other Students, or Third Parties, 62 Fed. Reg. 12034, 12036 (Mar. 13,1997 ) ("The Guidance has been clarified to indicate that if harassment is based on conduct of a sexual nature, it may be sexual harassment prohibited by Title IX even if the harasser and the harassed are the same sex or the victim of harassment is gay or lesbian."). In Nabozny v. Podlesny, 92 F.3d 446 (7th Cir. 1996), the court found that a school district discriminated on the basis of sex in violation of the Equal Protection Clause when it failed to protect a gay student 
includes sexual orientation within its definition of sex discrimination, ${ }^{9}$ and an Oregon court interpreted that state's law against sex discrimination to encompass a challenge to the denial of health insurance benefits to the partners of lesbian and gay state employees. ${ }^{10}$ One court outside the United States has invalidated a sexual orientation classification on the ground that it constituted sex discrimination under an international covenant. ${ }^{11}$ But beyond the principle that one can state a prima facie claim in such cases, there is no clarity as to what relationship exists between sex equality law and sexual orientation claims

It is time to pay more attention to this cluster of arguments. Other writers have explored the advantages and disadvantages of the sex discrimination argument for the goal of advancing lesbian and gay rights law. ${ }^{12}$ Instead, I would like to try to fill what I see as an unfortunate gap in the analysis. Scholars whose primary field is women's rights have generally ignored the possible repercussions

from harassment. Schools, the court announced, "are required to give male and female students equivalent levels of protection." Id. at 456.

${ }^{9}$ WIS. STAT. § 111.36(1)(d)(1) (1997 \& Supp. 2000).

${ }^{10}$ Tanner v. Oregon Health Sci. Univ., 971 P.2d 435 (Or. App. 1998).

11 Toonen v. Australia, Communication No. 488/1992, U.N. Doc CCPR/C/50/D/488/1992 (1994), available at http://www 1.umn.edu/humanrts/undocs/html/vws488.htm. The Human Rights Committee, an international body created under the Optional Protocol to the International Covenant on Civil and Political Rights ("ICCPR"), held that the Tasmanian Criminal Code provisions outlawing private consensual contacts between adult homosexual men was a violation of the ICCPR, as a violation of privacy and the ICCPR's equal protection mandate, because the laws discriminated on the basis of sexual orientation. Id. But see Case C-249/96, Grant v. Southwest Trains Ltd., 1998 E.C.J. CELEX LEXIS 6505 (1998) (rejecting the sex discrimination argument on the ground that the limitation of certain benefits to married persons treated men and women equally). See generally Robert Wintemute, Recognising New Kinds of Direct Sex Discrimination: Transsexualism, Sexual Orientation and Dress Codes, 60 MoD. L. REV. 334 (1997).

${ }^{12}$ See, e.g., Andrew Koppelman, Why Discrimination Against Lesbians and Gay Men Is Sex Discrimination, 69 N.Y.U. L. REV. 197 (1994); Samuel A. Marcosson, Harassment on the Basis of Sexual Orientation: A Claim of Sex Discrimination Under Title VII, 81 GEO. L.J. 1 (1992); Francisco Valdes, Queers, Sissies, Dykes and Tomboys: Deconstructing the Conflation of "Sex," "Gender," and "Sexual Orientation" in Euro-American Law and Society, 83 CAL. L. REV. 1 (1995). 
for sex discrimination law of using that claim in sexual orientation cases, with the prominent exception of Sylvia Law, who wrote the first major article on the topic. ${ }^{13}$ I want to initiate discussion of the possible reverberations for feminist law, as well as for lesbian, gay, bisexual and transgender ("LGBT") rights law.

I am going to discuss these cases in terms of the leading paradigms of sex discrimination law. Because I want to focus on constitutional concepts of equality, my most frequent example will be marriage law, where the argument has been most fully developed. I am not going to address claims arising under anti-discrimination statutes, such as the harassment cases.

My beginning point will be the two primary conceptualizations of sex discrimination: formal equality theory and anti-subordination theory. ${ }^{14}$ Both of these theoretical approaches have been invoked in the scholarship concerning the use of sex discrimination arguments in LGBT cases, and either is sufficient to sustain a finding that sex discrimination exists. In turn, such rulings in LGBT rights cases are likely to have a significant impact on understandings of how law operates to subordinate women.

Ultimately, though, I am going to argue that neither approach is culturally sufficient to meet the objections of those who assert that the sex discrimination argument is a doctrinal sleight of hand when used to challenge sexual orientation discrimination. To fully answer those objections, one must address the issues that arise in the context of what I will call definition theory. Definition theory is the most provocative of the approaches to these overlapping areas. Because of its provocative nature, definition theory is the least useful in litigation, but also the most powerful in its potential cultural impact.

${ }^{13}$ Sylvia A. Law, Homosexuality and the Social Meaning of Gender, 1988 WIS. L. REV. 187 (1988).

${ }^{14}$ See Kathryn Abrams, The Constitution of Women, 48 ALA. L. REV. 861 (1997). For simplicity's sake, I am combining two of Abrams' categories difference theory and dominance theory - into anti-subordination theory. 


\section{FORMAL EQUALITY THEORY}

Formal equality is considered the old, boring version of civil rights law. Critics have attacked it for its superficiality and formalism, ${ }^{15}$ and despite its usefulness in removing explicit legal barriers for women, it is rarely described positively in feminist scholarship. ${ }^{16}$ In fact, claims of sex discrimination in gay rights cases may be the only realm in which formal equality theory still has any real intellectual kick.

For an analysis of using sex discrimination arguments in gay rights cases, the starting point for formal equality claims is Loving $v$. Virginia ${ }^{17}$ the case which held that anti-miscegenation laws were unconstitutional. In Loving, the Court ruled that laws prohibiting intermarriage violated the Equal Protection Clause because they were based on a racial classification. This, the Court said, was per se impermissible - absent a compelling state interest - even if the law operated to bar certain acts both for whites and for persons of color.

In gay marriage cases, courts adopting a formal equality analysis substitute the word "sex" for the word "race" in a critical passage from Loving, so that, rewritten, it becomes:

${ }^{15}$ See, e.g., Sylvia A. Law, Rethinking Sex and the Constitution, 132 U. PA. L. REV. 955 (1984); Christine A. Littleton, Reconstructing Sexual Equality, 75 Cal. L. REV. 1279 (1987).

${ }^{16}$ For a rare endorsement, see Mary Anne Case, "The Very Stereotype the Law Condemns": Constitutional Sex Discrimination Law as a Quest for Perfect Proxies, 85 CORNELl L. REV. 1447 (2000) (proposing that formal equality, or anti-differentiation, is an attractive principle, even though it is less fashionable today than the alternate anti-subordination principle, because formal equality does not lead to the separate-but-equal thinking that results from applying the antisubordination principle, as evidenced by Chief Justice Rehnquist's concurring opinion in United States v. Virginia, 518 U.S. 515, 565 (1996)). A similar disjuncture between equality theories that are successful in litigation and those most favored by scholars occurs in LGBT cases between arguments grounded in more individualist notions of rights and those proceeding from a group rights approach. Nancy Levit, A Different Kind of Sameness: Beyond Formal Equality and Antisubordination Strategies in Gay Legal Theory, 61 Оніо ST. L.J. 867, 870 (2000).

17388 U.S. 1 (1967). 
[W]e reject the notion that the mere 'equal application' of a statute containing [sex] classifications is enough to remove the classifications from the Fourteenth Amendment's proscriptions of all invidious discrimination. ... In the case at bar, ... we deal with statutes containing [sex] classifications, and the fact of equal application does not immunize the statute from the very heavy burden of justification which the Fourteenth Amendment has traditionally required of state statutes drawn according to [sex $]^{18}$

Thus by analogy, Loving stands for the proposition that but for the partner's sex, the individual could marry her or him. The same move leads to a similar conclusion as the discriminatory impact of criminal laws that prohibit sodomy only between same sex partners: "the distinction between legal and illegal conduct [is] not the act, but rather the sex of one of the participants."19 On this understanding, the sex-based classification per se is the equality violation.

This theory of equality formed the basis for the Hawaii Supreme Court's ruling that the marriage law amounted to discrimination based on $\operatorname{sex}^{20}$ and for the invalidation of the Texas state sodomy law by the Texas Court of Appeals. ${ }^{21}$ Yet there have always been two problems lurking in the heart of formal equality doctrine about sex. They both manifest themselves in the sexual orientation cases generally and the marriage cases specifically.

The first major problem for formal equality doctrine arises if the two groups in question are not considered similarly situated. For men and women, the argument has always been that commensurability is lacking because of biological difference. In the early 1970 s, faced with the argument that "natural" differences justified a wide range of barriers to women, Ruth Bader Ginsburg, then head of the ACLU Women's Rights Project, flipped the meaning of

18 Id. at 8.

${ }^{19}$ Lawrence v. Texas, No. 14-99-00109-CR, 2000 WL 729417, *3 (Tex. App., June 8, 2000).

${ }^{20}$ Baehr v. Lewin, 852 P.2d 44, 81-82 (Haw.), recons. granted in part, 875 P.2d 225 (Haw. 1993).

${ }^{21}$ Lawrence, $2000 \mathrm{WL} 729417$, at $* 4$. 
biology in her arguments to the Court in Reed v. Reed ${ }^{22}$ and Frontiero $v$. Richardson. ${ }^{23}$ She argued that the immutability of the sex characteristic and the individual's lack of control over it made using it to justify inferior treatment all the more invidious and unfair. ${ }^{24}$ Ginsburg "had effectively taken what had previously been the greatest weakness of equal protection arguments against sex-based classifications and made it the center of the case." 25

Ginsburg's move was a masterful litigation stroke, but it also left unchallenged - indeed, it strengthened - the link between sexual difference and biology. Her argument forced the Court to examine more closely the legal barriers to individual women who sought the opportunity to disprove a generalization based on their female status, but left open the continued reliance on biological norms in cases involving sex and reproduction, arenas where seemingly no woman could escape the "rule" of nature, at least as the courts interpreted that rule. ${ }^{26}$

22404 U.S. 71 (1971).

${ }^{23} 411$ U.S. 677 (1973).

${ }^{24}$ See, e.g., Brief for Appellant, at 5, Reed v. Reed, 404 U.S. 71 (1971) (No. 70-430). Ginsburg began her appeal with an argument that sex, like race, deserved "suspect classification" status because sex and race shared many of the same characteristics:

Although the legislature may distinguish between individuals on the basis of their need or ability, it is presumptively impermissible to distinguish on the basis of an unalterable identifying trait over which the individual has no control and for which he or she should not be disadvantaged by the law. Legislative discrimination grounded on sex, for purposes unrelated to any biological difference between the sexes, ranks with legislative discrimination based on race, another congenital, unalterable trait of birth, and merits no greater judicial deference.

Id.

${ }^{25}$ Donald Braman, Of Race and Immutability, 46 UCLA. L. REV. 1375, 1453 (1999).

${ }^{26}$ See Michael M. v. Superior Court of Sonoma County, 450 U.S. 464,469 (1981) (holding that as long as the rule of nature that the sexes are not similarly situated in certain circumstances is realistically reflected in a gender classification, the statute will be upheld as constitutional; here, a California statutory rape law was found constitutional because the gender classification realistically reflected that females bear all of the risk of pregnancy); Geduldig v. Aiello, 417 U.S. 484, 494-95 (1974) (holding that the rule of nature that women, unlike men, 
The manipulability of biology-based arguments is evident in the opposite uses, depending on outcome, to which they can be put. In women's rights cases, courts have justified different treatment based on a finding of "real" difference, most often involving pregnancy. In the gay marriage cases, courts have justified different treatment because of the absence of biological difference, on the theory that the institution of marriage requires difference. ${ }^{27}$ In other words, the biological difference between sexes has been invoked to create an exemption from the equality mandate in pregnancy cases and a prerequisite for it in gay marriage cases.

Judicial reliance on (what judges perceive as) biology reflects and reinscribes a deep naturalization of gender. Thus, when courts like the Hawaii Supreme Court reject the argument that marriage is necessarily only male-female, they are undermining the kind of essentialism that has been most harmful to women. Even simple formal equality claims in gay marriage cases can provide a powerful lift out of some of the essentialist boxes used to hold back women, because they interrogate deeply embedded notions of gender.

One can see the dynamics of the naturalization of gender in the text of now Justice Ginsburg's opinion in the VMI case:

are susceptible to the risk of disability resulting from normal pregnancy does not require a state disability insurance program to cover this condition because the Equal Protection Clause does not require a state to choose between attacking every risk of disability versus not attacking disability problems at all); see also Wendy Williams, Equality's Riddle: Pregnancy and the Equal Treatment/Special Treatment Debate, 13 N.Y.U. REV. L. \& SoC. CHANGE 325 (1985). The Pregnancy Discrimination Act established protection for pregnant women in the realm of employment, but not, for example, in family law or criminal law. 42 U.S.C. $\$ 2000 \mathrm{e}(\mathrm{k})(2000)$. Thus, Geduldig is still good law as an interpretation of the Constitution. Even the Pregnancy Discrimination Act has not always proven reliable in eliminating differential treatment of pregnant women. See, e.g., Chambers v. Omaha Girls Club, Inc., 834 F.2d 697 (8th Cir. 1987). But see Int'l Union, UAW v. Johnson Controls, Inc., 499 U.S. 187 (1991).

The Court's most recent engagement with the constitutionality of a pregnancy-linked classification ended inconclusively, when the Court found no standing for the party challenging an immigration law that treated children born to unmarried parents differently depending on whether the father or mother was a U.S. citizen. Miller v. Albright, 523 U.S. 420 (1998).

${ }^{27}$ See, e.g., Baehr, 852 P.2d at 69 (Burns, J., concurring). 
Supposed 'inherent differences' are no longer accepted as a ground for race or national origin classification [citing Loving]. . . Physical differences between men and women, however, are enduring. . . 'Inherent differences' between men and women, we have come to appreciate, remain cause for celebration, but not for denigration of the members of either sex or for artificial constraints on an individual's opportunity. ${ }^{28}$

The text of this passage moves from "inherent differences" as a discredited basis for certain classifications, to "physical differences" between the sexes, and back to "inherent differences." 29 Are the two terms synonymous? Is this a sly way to exclude psychological differences from the final phrase, which was largely the basis for VMI's argument that women were naturally unfit to be cadets at a co-education facility ? $^{30}$ Exactly which differences are we to celebrate? Is this a euphemism for heterosexuality? For female bonding? Doesn't the last sentence incorporate two contradictory principles: that these inherent differences, as contrasted to racial ones, are proper grounds for classification - but not for "artificial" constraints on an individual?

Indeed, the Loving analogy helps to obscure that contradiction, since it is based on an analogy to race, the realm where indisputably there is no place for a separate but equal doctrine. The Court's decision in Loving signaled that the repudiation of separate but equal, which the court began in Brown v. Board of Education, ${ }^{31}$ was complete. That consensus has not formed as to gender, as to which there is still substantial support for separate institutions. For gender, unlike race, the cultural orthodoxy is difference. What

${ }^{28}$ United States v. Virginia, 518 U.S. 515,533 (1996).

${ }^{29} I d$.

${ }^{30}$ See United States v. Virginia, 766 F. Supp. 1407, 1432-35 (W.D. Va. 1991) (listing in detail the evidence presented by VMI during trial, arguing that the "Gender-Based Physiological Differences" and the "Gender-Based Developmental Differences" between male and female students were appropriate reasons for limiting VMI to an all-male educational facility); see also Amy H. Nemko, Single-Sex Public Education After VMI: The Case for Women's Schools, 21 HARV. WOMEN'S L.J. 19, 44-45 (1998).

31347 U.S. 483 (1954). 
would be the philosophy comparable to race - gender blindness is not widely accepted in the culture.

Gender is most naturalized in the realm of sexuality. Same-sex marriage cuts to the heart of that naturalization in a very powerful and visible way. ${ }^{32}$ Recognition of same-sex marriage would call into question the law in women's rights cases, which have turned on an acceptance of the inevitability of sex roles in sex. Often such cases have permitted the differential treatment of pregnancy, or of women because of the possibility of pregnancy. ${ }^{33}$ Although heterosexual couples can reject sex roles in sex, the plausibility that such rejection occurs is more socially visible when same-sex couples are involved. Nonetheless, the potential is that acceptance of same-sex marriage would strengthen the consciousness in cases involving heterosexual women that such roles are not inevitable and ordained by nature.

\section{ANTI-SUBORDINATION THEORY}

The second problem with the formal equality model is that it ignores power. Discrimination against men really is not the same evil as discrimination against women, and one would say the same as to "reverse discrimination" against whites, for example. In both examples, the core of the problem is not the absence of abstract equality but the presence of subordinating systems of power. ${ }^{34}$ Anti-subordination theory speaks to this: sex discrimination not only classifies, it subordinates a class.

This concept of dominance has been the focus of almost all of the scholarship and almost none of the judicial decisions in the gay rights cases where plaintiffs have asserted a sex discrimination

${ }^{32}$ I developed this argument in Nan D. Hunter, Marriage, Law and Gender: A Feminist Inquiry, 1 LAW \& SEXUALITY 9 (1991).

${ }^{33}$ See supra note 26 (discussing pregnancy in the sex discrimination context).

${ }^{34}$ See Ruth Colker, Anti-Subordination Above All: Sex, Race and Equal Protection, 61 N.Y.U. L. REV. 1003 (1986) (arguing that, compared to the antidifferentiation perspective, anti-subordination better explains much of the equal protection doctrine's history and case law, as well as the aversion felt toward race and sex discrimination). 
claim. First Sylvia Law $^{35}$ and then Andrew Koppelman ${ }^{36}$ articulated the argument that anti-gay discrimination subordinates women hy its reinforcement of gender normative stereotypes about proper male and female behavior. Koppelman's article specifically answered the argument that reliance on the surface level analogy to Loving is insufficient because the Court there did not rely simply on the law's creation of a racial distinction; it held that the distinction did not in fact apply equally to all races, but was framed to enforce a code of white supremacist preservation of a "superior" race. ${ }^{37}$ Koppelman argued that a similar enforcement of male supremacy lay behind the prohibition of homosexuality. ${ }^{38}$ No judge has taken up that argument as part of the analysis of a gay rights case, but Justice Johnson's opinion in Baker v. Vermont provides a suggestive first step. ${ }^{39}$

The standard example in a formal equality approach of how the sex discrimination argument operates is that a court imagines two persons of the same sex; let us call them Thelma and Louise. Either can marry a man, but neither can marry the other. Because neither wants to marry a man and they are barred from marrying each other, they suffer discrimination based on the sex of their partner. $^{40}$

Justice Johnson used a version of this standard story, but one which can be read to illustrate a subtle but significant shift in the narrative. As Justice Johnson framed the example, Dr. A and Dr. B both want to marry Ms. C. Dr. A is male; Dr. B is female. "The statute disqualifies Dr. B from marriage solely on the basis of her

${ }^{35}$ Law, supra note 13.

${ }^{36}$ Koppelman, supra note 12; see also, J.M. Balkin, The Constitution of Status, 106 YALE L. J. 2313, 2361-64 (1997).

${ }^{37}$ Loving v. Virginia, 388 U.S. 1, 11 (1967); see also Koppelman, supra note 12 , at $222-26$.

${ }^{38}$ Koppelman, supra note 12 , at $234-57$.

${ }^{39}$ Baker v. Vermont, 744 A.2d 864, 898 (Vt. 1999) (Johnson, J., concurring).

${ }^{40}$ See, e.g., Cass R. Sunstein, Homosexuality and the Constitution, 70 IND. L.J. 1, 18 (1994) (discussing how the courts have viewed bans on same-sex marriage as sexual orientation discrimination, and not sex discrimination). 
sex and treats her differently from Dr. A, a man. This is sex discrimination."

What is slightly different about this framing is that there is a third person in the imaginary construct, Ms. C, who is presumably choosing between Dr. A and Dr. B. This scenario has a different resonance than the more familiar story of two women who are simply excluded from the institution of marriage. In my reading of Justice Johnson's version, the social force of law is not simply to exclude based on sexual orientation or to penalize Dr. B., but to produce heterosexuality. One imagines that Ms. C could go either way. If she wants to marry, however, she must choose Dr. A. Implicit in the example is that the harm is in the social coercion of Ms. C and in the forcible imposition of heteronormativity. ${ }^{42}$

Justice Johnson sees the limitation to opposite-sex marriage as a vestige of the "sex-role stereotyping" that pervaded marriage law prior to feminist legal reforms, citing enforced economic dependency and the treatment of married women as legal incompetents as examples. ${ }^{43}$ Again, one can see the point as not merely discriminatory treatment, but the role of the law of marriage as a major engine of coercion for almost all women. Under an anti-subordination theory as well as a formal equality theory, one can trace a clear link between how classifications based on sex have produced social regulation of women as well as of non-heterosexuals.

To some extent, this link appears self-evident in everyday life. We all know that eliminating discriminatory laws opens up new

${ }^{41}$ Baker, 744 A.2d at 906. (1989).

42 See Jed Rubenfeld, The Right of Privacy, 102 HARV. L. REV. 737, 800

${ }^{43}$ Baker, 744 A.2d at 908 (Johnson, J., concurring). Justice Johnson offered numerous examples of a woman's dependence on her husband:

Under the common law, husband and wife were one person. The legal existence of a woman was suspended by marriage; she merged with her husband and held no separate rights to enter into a contract or execute a deed. She could not sue without her husband's consent or be sued without joining her husband as a defendant. Moreover, if a woman did not hold property for her "sole and separate use" prior to marriage, the husband received a freehold interest in all her property, entitling him to all the rents and profits from the property.

Id. (citations omitted). 
life possibilities and creates subtle shifts in perception. Changes in the popular language of marriage mark that evolution: from the traditional terms of "husband and wife" - or even, "man and wife" - that once were universal; to the now common gender neutral word, "spouses;" to the increasingly widespread use of the term that originated with lesbian and gay couples, "partners."

Nonetheless, there is much resistance to the full elaboration of the gender discrimination argument. If anti-gay discrimination is so harmful to women, for example, one might ask why more women's rights organizations have not been highlighting this argument. All of the feminist organizations support a right to gay marriage, and many have played supportive roles in the litigation. ${ }^{44}$ But one has no sense that anyone, including them, feels like this is their argument. Granted, any claim is more radical when it touches homosexuality, but many sex discrimination cases involve gender normative stereotypes. Is there a reason beyond political hesitancy that this argument has so much difficulty acquiring traction on the ground?

To many people, including many feminists, the sex discrimination argument in gay rights cases seems too clever by half. For some, that is because it seems to be a dodge around what they sense is really going on, which is the subordination of homosexuality. ${ }^{45}$ For many married women, it apparently is highly implausible to believe that legalizing same-sex marriage will have any impact on opposite-sex marriage. Among my straight women students, for example, most support gay marriage out of a sense of solidarity with another oppressed group. To their credit, it is a

${ }^{44}$ See, e.g., Brief of Amici Curiae National Organization for Women Legal Defense and Education Fund, National Center for Lesbian Rights and Equal Rights Advocates, Baker v. Vermont, 744 A.2d 864 (Vt. 1999).

${ }^{45}$ This is the argument made from the opposite policy perspective by the dissenting judge in Lawrence. Lawrence v. Texas, No. 14-99-00109-CR, 2000 WL 729417, *5 (Tex. App., June 8, 2000) (Hudson, J., dissenting). "Although [complainants] have attempted to frame their challenge . . in terms of gender discrimination, their true ground for complaint is that the statute criminalizes certain homosexual conduct that, in a heterosexual setting, would be perfectly legal." Id. at 7. 
purely altruistic position. They appear to have no sense that it will do anything for them.

Critics argue that the exclusion of same-sex couples from marriage does not harm women as a class, but gay people as a class. Bill Eskridge points out that the same argument could have been made for anti-miscegenation laws. ${ }^{46}$ Those laws had a direct effect only on the mixed-race couples who wanted to marry, not on all African-Americans. Furtherance of the white supremacist ideology that the laws embodied was an indirect effect. Eskridge ultimately returns to the Koppelman thesis, arguing that dominance theory works if the subordination is indirect as well as direct. ${ }^{47}$

Edward Stein has responded to Eskridge and others, asserting that the sex discrimination argument is sociologically, theoretically and morally mistaken. ${ }^{48}$ Stein asserts that relying on a sex discrimination theory in a gay marriage case is to ignore the primary basis for the discrimination: homophobia. He analogizes it to a sex discrimination challenge to anti-miscegenation laws, which could be premised on the understanding that "a significant purpose of such laws was to protect white women from black men," but which would misidentify the disadvantaged class (by asserting that it was women) and the belief system underlying the law (by focusing on sexism rather than racism). ${ }^{49}$

There is, however, a crucial distinction between using a sex discrimination argument in the anti-miscegenation cases and using one in the gay marriage cases. The statute at issue in Loving explicitly discriminated based on race. Although I would agree with Stein that sex and race are deeply interconnected in U. S. culture, the law on its face did not draw a sex-based distinction. It could have; a legislature could have chosen to specify differential penalties when an inter-racial marriage involved black men and

${ }^{46}$ WILliam N. ESKRIDGE, JR., GAYLAW: ChallENGing THE APARTHEID OF THE CLOSET 220-21 (1999).

${ }^{47}$ Id. at 221.

${ }^{48}$ Edward Stein, Sexual Orientation and the Law: A Critique of Two Arguments for Lesbian and Gay Rights, in HANDBOOK OF JURISPRUDENCE AND LEGAL PHILOSOPHY 43-53 (Jules Coleman \& Scott Shapiro eds., forthcoming 2001) (copy on file with the Journal of Law and Policy).

${ }^{49} I d$. at 43. 
white women, for example. Although that might have been the deepest fear of white legislators, they did not incorporate that distinction into those statutes.

In the gay marriage cases, on the other hand, the explicit classification drawn by the statutes is one of sex. Although the arguments used to justify the statutes might be homophobic, the legislators have not chosen to classify based on sexual orientation. The unlikelihood that they will - the improbability of states adopting laws that prohibit homosexual persons from marrying speaks to the deeply imbricated nature of sex and sexual orientation. Legislators may well understand their actions as penalizing homosexuals rather than women, and especially as penalizing open homosexuality, but the fact that what seems the most direct and obvious mechanism for doing so is a distinction based on sex rather than sexual orientation illustrates how this situation is different from that of Stein's hypothetical sex discrimination challenge to anti-miscegenation laws.

It is also worth pointing out that, however favored by progressive scholars, anti-subordination theory is not the law. The antisubordination language of Loving was dicta; ${ }^{50}$ the reliance on color-blindness and formal neutrality in constitutional jurisprudence has increased, not decreased, since that decision. ${ }^{51}$ If courts were to assert the inadequacy of anti-subordination reasoning as a doctrinal bar to sex discrimination claims in gay marriage cases, that rationale would reek of intellectual dishonesty.

Most significant for women as a class, rather than LGBT people as a class, is the function of sex-based distinctions to produce and enforce norms that privilege masculinity. Although

50 The Court held that use of an explicit racial classification was sufficient to find the law unconstitutional. See Loving, 388 U.S. at 10-11.

${ }^{51}$ See, e.g., Neil Gotanda, A Critique of "Our Constitution Is Color-Blind," 44 STAN. L. REV. 1 (1991) (detailing the modern Court's progression from the explicit recognition of racial differences in cases like Brown $v$. Board of Education, where the Court endorsed the distinction to right a prior wrong; to the modern Court's more explicit attempts to adopt a purely race-neutral approach, rejecting any law relying on any types of racial classifications, even those establishing corrective elements, such as affirmative action). 
such norms may also constrain some men, what matters for purposes of this analysis is that they constrain all women.

\section{DEFINITION THEORY}

Gender-linked stereotypes about sexuality are not just about behavior. They are about what people perceive as definition, and that definition turns on the naturalness and the thoroughness of male-female difference. Thus there is some truth to the trope of the early gay marriage cases that the claim could not succeed because of the very definition of marriage. The use of sex discrimination arguments in these gay rights cases profoundly challenges the definition of gender, and will inevitably resonate in women's rights cases.

I think that there are two logics possible for answering the definition argument directly. The first, which I reject, is to argue that heterosexual sexual behavior itself is intrinsically determined by gender roles. Sexuality is a knowledge/power system that is gendered and through which gender flows, but I do not believe that sexual practices are a simple function of gender. The social organization and understanding of sexual practices cannot be reduced to a function of gender. ${ }^{52}$

The other logical response, which I embrace, is what I will call definition theory. It is precisely the act of defining male and female, masculinity and femininity, which inscribes gender. ${ }^{53}$ Koppelman discussed the function of gender polarities in perpetuating a dominance system, noting that polarities enable hierarchy. ${ }^{54}$ Definition theory takes that point deeper. It is in the process of definition that the difference is constructed.

52 See Gayle Rubin, Thinking Sex: Notes for a Radical Theory of the Politics of Sexuality, in Pleasure AND DANGER: EXPLORING FEMALE SEXUALITY 267319 (Carole S. Vance ed., 1984).

53 See, e.g., ANNE FAusto-STERLing, Myths of GENDER: Biological THEORIES ABOUT WOMEN AND MEN passim (1989) (studies from biology); Thomas LaQueur, MAKING SEX: Body AND GENDER FROM THE GREEKS TO FREUD passim (1992) (studies from history); JUDITH BUTLER, GENDER TROUBLE: FEMINISM AND THE SUBVERSION OF IDENTITY 6-7 (1990) (cultural studies).

${ }^{54}$ Koppelman, supra note 12 , at 202, 234-38. 
Katherine Franke has most fully developed this idea as it applies to the operations of law. ${ }^{55}$ Franke argues that the process of definition, "[t]he authority to define particular categories or types of people and to decide to which category a particular person belongs," is a social practice that reflects dominant power structures, not self-evident facts of nature. ${ }^{56}$ In the realm of sex distinctions, she examines a series of cases that turn on an "ideology of sexual difference," facts. ${ }^{58}$ Her conclusion is that "[b]iology is both a wrong and

55 See Katherine M. Franke, The Central Mistake of Sex Discrimination Law: The Disaggregation of Sex from Gender, 144 U. PA. L. REV. 1 (1995).

56 Id. at 3 .

${ }^{57}$ Id.

${ }^{58}$ Franke describes a number of seemingly inconsistent rulings, including the following:

In Corbett v. Corbett, 1971 P. 83 (1970), an English court was asked to determine whether or not April Ashley was a woman at the time of her marriage to Arthur Corbett, a man. Born a man, but having undergone a successful sexreassignment surgery, Ms. Ashley had "remarkably good' female genitals," had female hormonal levels, and "passed easily as a woman." Franke, supra note 55, at 45. Yet, at all times, she had male chromosomes; thus, the court determined, "an individual's sex is permanently fixed at birth and cannot be later changed. ..." Franke, supra note 55, at 46. In deciding that Ms. Ashley was, at the time of the marriage, "a man," the court noted plainly: "these submissions, in effect, confuse sex with gender. Marriage is a relationship which depends on sex and not on gender." Franke, supra note 55, at 47.

In City of Columbus v. Zanders, 266 N.E.2d 602 (Ohio Mun. 1970), in the context of criminal sumptuary laws, a Columbus, Ohio, court convicted a preoperative male to female transgendered person who was arrested three times for dressing as a woman. Zanders was fulfilling part of his pre-operative therapy. The court upheld the conviction, although noting that the sumptuary laws operated to reinforce gender norms, on the ground that the law prevented the cross-dresser from perpetrating a fraud on the general public. Franke, supra note 55, at 66. A year later, however, the Ohio Supreme Court struck down the same statute for lack of a scienter requirement. City of Columbus v. Rogers, 324 N.E.2d 563 (Ohio 1975); Franke, supra note 55, at 68. The removal of the law permitted a biological male such as Zanders to appear publicly as a woman.

And in Faulkner v. Jones, 858 F. Supp. 552 (D.S.C. 1994), the court was asked to allow the plaintiff, a woman, access to the Citadel, an exclusively male military college. The court considered that there were "some real differences between men and women," and thus there were some legitimate reasons for accommodating those differences. Id. at 563. The court focused, however, not on 
dangerous place to ground antidiscrimination law because it fails to account for the manner in which every sexual biological fact is meaningful only within a gendered frame of reference."59

Janet Halley has made a comparable point about the definition of sexual orientation and the roles of law in constructing and enforcing homo- or heterosexuality. ${ }^{60}$ Halley points out that the legal definition of homosexuality changes depending on context; as one moves from sodomy law discourse to adoption laws to military regulations, the same individual might be first defined into, then out of, the category of homosexual. ${ }^{61}$ In some instances (but not others), the disjuncture between gender role behavior and anatomical sex is determinative. ${ }^{62}$ In the gay marriage cases, those constitutive forces of law - the construction of sex and of sexual orientation - converge.

I will admit that the phrase "definition theory" is provocative, perhaps unnecessarily so. Either of the other approaches is doctrinally sufficient to sustain a sex discrimination claim, and this is the most controversial framing of a justification. I use it to intentionally invoke what opponents of gay marriage have relied on as their primary argument, the assertion that the very definition of

any "real" differences - meaning biological or even gender-based. Rather, the court focused on the need for privacy in public restrooms. Franke's response: "Yet there are no significant differences in male and female anatomy that require separate and distinct sanitary facilities. Although privacy may be an important cultural value, it is not a 'real difference' of the kind courts demand when it requires that separate facilities be justified by real and demonstrative differences." Franke, supra note 55, at 82 . Ultimately, however, the court held for the plaintiff, and Shannon Faulkner entered the Citadel. Faulkner, 858 F. Supp. at 569.

${ }^{59}$ Franke, supra note 55, at 98.

${ }^{60}$ Janet E. Halley, The Politics of the Closet: Toward Equal Protection for Gay, Lesbian and Bisexual Identity, 36 UCLA L. REV. 915, 948-56 (1989); Janet E. Halley, The Construction of Heterosexuality, in FEAR OF A QUEER PLANET: QUEER POLITICS AND SOCIAL THEORY 82-102 (Michael Warner ed., 1993).

${ }^{61}$ Halley, The Politics of the Closet, supra note 59, at 948-56.

${ }^{62}$ See Patricia Klein Lerner, Jailer Learns Gay Culture to Foil Straight Inmates' Crime, L.A. TIMES, Dec. 27, 1990, at B1 (describing the process of segregating gay inmates in a men's prison in Los Angeles to protect them from the general prison population, and guarantee them the same rights and privileges of other prisoners). 
marriage requires an opposite-sex couple. The point is not whether marriage has always been understood to be defined that way, ${ }^{63}$ or even that the definition relies on an impermissible classification, as "voter" once was defined as white or male. The more fundamental claim is that current marriage law actively creates and enforces gender hierarchy by constructing the social meaning of male-female difference. ${ }^{64}$ Although Franke does not invoke marriage as an example of her theory, in many respects it is the prime example of "an ideology of sexual difference."

An argument that marriage can exist without sexual difference implies that gender polarity is not essential for a (perhaps the) primary social unit. Such dispensability indicates that gender's perceived salience and importance have been more the product of social structures and processes than of biology or nature. That notion can be simultaneously discomforting and liberatory for women (as well as for men).

Perhaps in part as a result of the ambivalence among women, a curious divergence is developing between judicial reasoning and social perception in the LGBT cases decided on sex discrimination grounds. Despite holdings based on a finding of sex discrimination, the rulings are accepted (to the extent that they are) and described in popular media as being about "gay rights." The problem with this development is not only that the courts duck a confrontation with the anti-gay animus which is at work, as discussed supra, but the potential liberatory impact of such rulings is sharply truncated. The primary challenge, therefore, may be to feminist rights advocates: to claim the full meaning of such rulings and to interpret them socially, as well as legally, as victories for women.

\section{CONCLUSION}

As long as there is no federal statutory protection ${ }^{65}$ or height-

${ }^{63}$ For a strong argument that this belief is incorrect, see WILLIAM $\mathbf{N}$. ESKridge, JR., The CASE for SAME-SEX MARRIAGe 15-44 (1996).

${ }^{64}$ See Hunter, supra note 32.

${ }^{65}$ See Steven A. Holmes, Civil Rights Dance Lesson: The Tiny Step Forward, N.Y. TIMES, Sept. 15, 1996, at D5 (reporting on a Senate vote resulting in the defeat of the Employment Non-Discrimination Act, which would have 
ened constitutional scrutiny for sexual orientation claims, ${ }^{66}$ lawyers will continue to press the sex discrimination argument in LGBT cases. Whether conceptualized as formal equality, antisubordination or definition theory arguments, sex discrimination claims in LGBT rights cases will have major ramifications for "traditional" sex discrimination claims brought by women to challenge policies preferring men. Here, necessity is the mother of re-invention. And the possibility of re-inventing our understanding of what sex discrimination means is both a risk and an opportunity for women's rights advocates.

provided federal employment protections for lesbians and gay men).

${ }^{66}$ See Toni M. Massaro, Gay Rights Thick and Thin, 49 STAN. L. REV. 45 (1996); see also Kyle C. Velte, Paths to Protection: A Comparison of Federal Protection Based on Disability and Sexual Orientation, 6 WM. \& MARY J. WOMEN \& L. 323 (2000). 